\title{
A Case of Choroid Plexus Papilloma with Rare Location Presenting with Impaired Consciousness
}

\author{
Bilinç Bulanıklığı ile Başvuran Nadir Yerleșimli Koroid Pleksus Papillom Olgusu
}

\author{
(D) Nurcan Ünal1, (D) Muhammet Mesut Nezir Engin1, (D) Önder Kılıçaslan1, (D) Ibrahim Feyyaz Naldemir2, \\ (D) Gülșen Yalçın¹, (D) Uğur Avcıำ, (D) Kenan Kocabay¹
}

1Düzce University Faculty of Medicine, Department of Pediatrics, Düzce, Turkey

2Düzce University Faculty of Medicine, Department of Radiology, Düzce, Turkey

\begin{abstract}
Intraventricular papillary neoplasms originating from the choroid plexus epithelium are called choroid plexus tumors (CPT). In pediatric patients. The most common findings in CPT are seizures, subarachnoid hemorrhage, focal neurological deficits, hydrocephalus and symptoms of increased intracranial pressure. A 4.5-month-old, previously healthy girl was admitted to our Pediatric Emergency Department with complaints of inadequate nutrition, vomiting and drowsiness in the last 2 days. The patient was admitted to the pediatric intensive care unit and saline loading treatment was initiated due to presumed dehydration caused by inadequate nutrition. As dehydration-related pathology was not detected, brain tomography scan was performed for possible cranial pathology and it revealed increased bilateral lateral ventricular diameters. As a result of magnetic resonance imaging results, the patient was diagnosed as having choroid plexus papilloma. After the shunt was inserted, the patient regained consciousness and an elective surgery was planned. Inadequate nutrition and drowsiness are the most common causes of admissions to pediatric emergency department, and these symptoms are usually due to dehydration. Cranial pathologies should be considered in patients who do not respond to fluid loading treatments and whose laboratory findings and vital signs are stable. As in our patient, the patients with choroid plexus papilloma should be evaluated clinically and shunt surgery should be performed firstly. Timing of surgery should be decided according to the effect and clinical status.
\end{abstract}

Keywords: Choroid plexus papilloma, hydrocephalus, impaired consciousness

\section{öz}

Koroid pleksus epitelinden gelișen intraventriküler papiller neoplazilere koroid pleksus tümörleri (KPT) denir. Çocuk hastalarda KPT'de en sık görülen bulgular nöbetler, subaraknoid kanama, fokal nörolojik defisit ve hidrosefali ile artan kafa içi basıncın belirtileridir. Öncesinde sağlıklı olduğu öğrenilen 4,5 aylık kız hasta, son 2 gündür olan beslenme azlığı, bir kez kusma ve sonrasında gelișen uykuya meyil şikayeti ile çocuk acil servisimize başvurdu. Hasta pediatri yoğun bakım ünitesine yatırılıp ön planda beslenememeye bağlı dehidratasyon düşünülerek serum fizyolojik yükleme tedavisi bașlandı. Yapılan tetkiklerde dehidratasyona ait patoloji gözlenmemesi üzerine olası kraniyal patolojiler açısından çekilen bilgisayarlı beyin tomografisinde bilateral lateral ventriküler çaplarının normale göre artmış olduğu görüldü. Bunun üzerine çekilen manyetik rezonans görüntüleme sonuçları neticesinde hastaya koroid pleksus papillomu tanısı konuldu. Şant takıldıktan sonra hastanın bilinci açıldı, ileri dönemde elektif şartlarda operasyon planlandı. Beslenme azlığı ve uykuya meyil şikayetinin çocuk acil servisine en sık bașvurulardandır ve bu semptomlar genellikle dehidratasyona bağlıdır. Sıvı yükleme tedavilerine yanıt vermeyen, laboratuvar ve vital bulguları stabil olan hastalarda mutlaka kraniyal patolojiler düşünülmelidir. Bizim hastamızda olduğu gibi koroid pleksus papillomu tanısı konulan hastaların klinik durumu değerlendirilerek öncelikle hastalara şant takılması gereklidir. Sonrasında etki ve klinik duruma göre cerrahi tedavinin ne zaman yapılacağına karar verilmelidir.

Anahtar Kelimeler: Koroid pleksus papillomu, hidrosefali, bilinç bulanıklığı
Address for Correspondence/Yazıșma Adresi: Muhammet Mesut Nezir Engin, Düzce University Faculty of Medicine, Department of Pediatrics, Düzce, Turkey

Phone: +90 5426378810 E-mail: doktormesut@hotmail.com ORCID ID: orcid.org/0000-0002-0874-6857

Cite this article as/Atıf: Ünal N, Engin MMN, Kılıçaslan Ö, Naldemir IF, Yalçın G, Avcı U, Kocabay K. A Case of Choroid Plexus Papilloma with Rare Location Presenting with Impaired Consciousness. İstanbul Med J 2019; 20(2): 156-8

(c) Copyright 2019 by the Istanbul Training and Research Hospital/Istanbul Medical Journal published by Galenos Publishing House.

(C) Telif Hakkı 2019 Istanbul Ĕgitim ve Araștırma Hastanesi/Istanbul Tıp Dergisi, Galenos Yayınevi tarafından basılmıștır.
Received/Geliș Tarihi: 01.11.2017 Accepted/Kabul Tarihi: 16.05.2018 


\section{Introduction}

Choroid plexus is an epithelial tissue localized in the ventricles and secretes cerebrospinal fluid (CSF). Intraventricular papillary neoplasms originating from this epithelium are called choroid plexus tumors (CPT) (1). The most common symptoms of CPT in pediatric patients are hydrocephalus, signs of increased intracranial pressure (IICP), seizures, subarachnoid hemorrhage or focal neurological deficits (2). These tumors constitute $0.4-0.6 \%$ of all brain tumors. Fifty percent of the CPTs are localized in the lateral ventricle, $40 \%$ in the fourth ventricle and $5 \%$ in the third ventricle (1). As a result of meta-analyzes of cases published until 1998, it was seen that $45 \%$ of the papillomas were diagnosed in the first year and $74 \%$ were diagnosed in the first 10 years (3). In this case report, it was aimed to draw attention to choroid plexus papilloma (CPP) by presenting a rare CPP located in the third ventricle that was detected in a 4.5-month-old girl following admission for impaired consciousness.

\section{Case Report}

A 4.5-month-old, previously healthy girl was admitted to our Pediatric Emergency Department with complaints of inadequate nutrition, vomiting and drowsiness in the last 2 days. Her body temperature was $36.7{ }^{\circ} \mathrm{C}$, and heart and respiratory rates were within normal limits according to age. There was no abnormality in blood pressure. On physical examination, her general condition was poor and she was stuporous. The patient did not respond to the verbal stimulus and had a response to painful stimuli. Her skin was pale and mucous membranes were dry with decreased turgor. Other system examinations were normal. The patient was immediately hospitalized in pediatric intensive care unit and saline loading therapy was initiated due to presumed dehydration caused by inadequate nutrition. Blood gas analysis, complete blood count and biochemical tests were within normal ranges according to age. As there was no change in consciousness after fluid treatment, the blood pressure was within normal limits and there was no dehydrationrelated pathology. Imaging was planned for possible cranial pathologies. Because the anterior fontanel diameter was not appropriate for ultrasonography (USG), brain computed tomography (CT) was performed and it was seen that bilateral lateral ventricular diameters were increased compared to normal. In the magnetic resonance imaging (MRI) of the brain, an isointense, multilobulated mass lesion that was located in the third ventricular floor and was extending inferiorly along the cerebral aqueduct on unenhanced sagittal T1-weighted image (Figure 1a). There was a homogenous contrast enhancement on enhanced sagittal T1weighted image (Figure 1b). At the same time, the third ventricle and lateral ventricles were enlarged on the coronal T2-weighted image (Figure 2). The diagnosis of CPP was made by MRI results. The patient underwent a shunt surgery for hydrocephalus at an external healthcare center and the patient regained consciousness. Follow-up was planned for the patient and future elective surgery was decided. Informed consent was obtained from relatives of the patient.

\section{Discussion}

CPP is a rare congenital tumor of neuroectodermal origin in children and adults (4). Choroidal plexus tumor was classified as grade 1, 2 and 3 by World Health Organization, and they were named as CPP, atypical
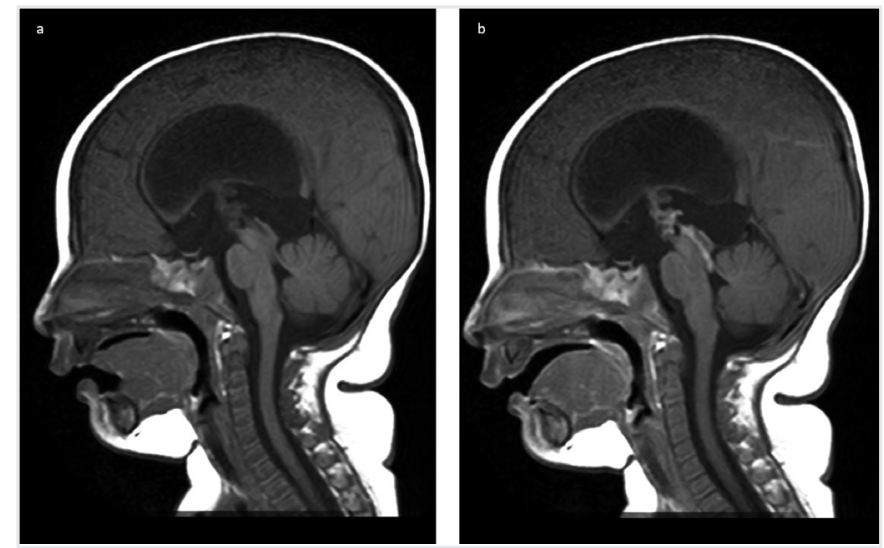

Figure 1. a) At Sagittal T1WI, isointens multilobulated mass, located at the base of third ventricle and extending down along the aquaductus cerebri b) After administration of contrast medium, heterogeneous enhancement was noted

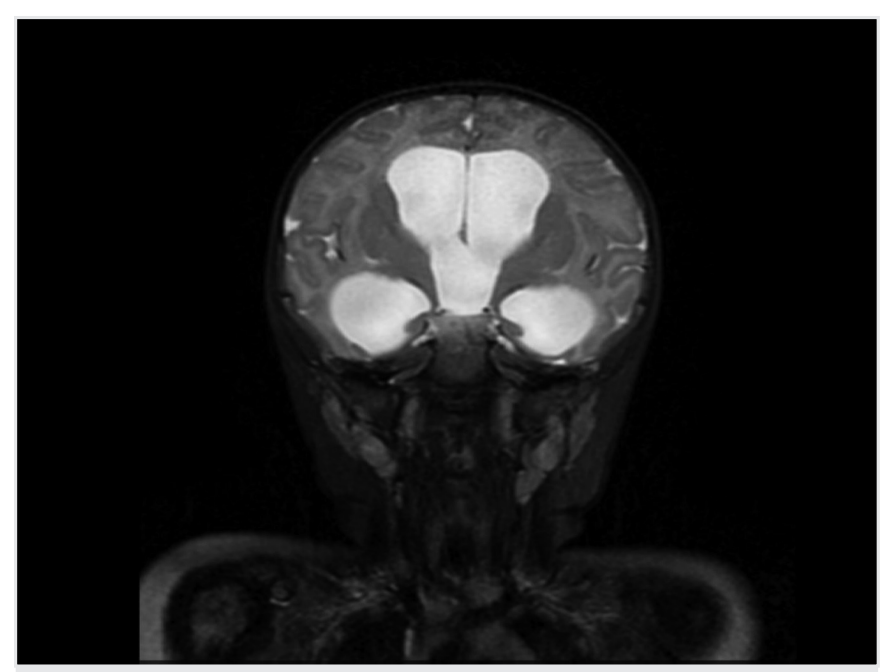

Figure 2. At coronal T2WI; marked dilatation 3. and lateral ventricles

CPP, and choroid plexus carcinoma, respectively (5). Due to mechanical obstruction, hydrocephalus in CPTs is frequently caused by the spread of the mass and excessive secretion of CSF. As in our case, clinical findings in CPTs, especially in papillomas, are always associated with accompanying hydrocephalus. The symptoms of these tumors include head enlargement, bulging fontanelle, papilledema, diplopia due to paralysis of $6^{\text {th }}$ cranial nerve, seizures, ataxia, nausea/vomiting, motor and sensory disorders, restlessness and disturbances of consciousness (1). Our patient had inadequate nutrition, impaired consciousness, vomiting and drowsiness. As the fontanel does not close in children under one year of age, symptoms due to IICP are slower and it may present as inadequate nutrition as in our patient.

Differential diagnosis is very important for follow-up and appropriate treatment. The diagnosis of brain tumors can be made by $\mathrm{CT}$, but MRI is the gold standard for treatment planning and follow-up. In CT, CPPS appear iso- to hyperdense in the intraventricular area and sometimes include microcalcifications (6). Bilateral lateral ventricular diameters were larger than normal in CT scan of our patient. The lesion shows 
homogeneous isointensity on T1-weighted images and hyperintensity on T2-weighted images in MRI, as in our patient (5).

The first treatment option is surgery. Postoperative radiotherapy is recommended if the patient has undergone subtotal excision and the patient is over 3 years of age. Radiotherapy is not recommended in patients younger than 3 years of age because it may cause neurological complications in the developing brain (1). The patient had undergone shunt operation because of hydrocephalus detected in her CT scan. Because of the small size of the tumor and good prognosis of the patient, no additional surgical intervention was performed and radiotherapy was not applied since our patient was under 3 years of age.

The factors associated with prognosis in CPP are symptoms, the size and the location of the tumor (5). In CPP, 1,5-year survival rates were reported as $90 \%, 81 \%$ and $71 \%$, respectively (7).

\section{Conclusion}

Inadequate nutrition and drowsiness are the most common causes of admissions to Pediatric Emergency Department and are usually due to problems, such as dehydration, which can be solved by rapid treatment in the emergency department. Etiologic evaluation must be performed before initiating fluid therapy in patients without signs of dehydration. Cranial pathologies should be considered in the differential diagnosis in patients who do not respond to fluid loading treatments and who has persistent impaired consciousness despite stable laboratory findings and vital signs. Transfontanelle USG or cranial CT should be performed according to the fontanel diameter in these patients and MRI should be performed to clarify the diagnosis and follow-up the patient if a pathology is detected.
Informed Consent: Informed consent was obtained from relatives of the patient.

Peer-review: Externally peer-reviewed.

Author Contributions: Concept - Ö.K.; Design - N.Ü., I.F.N.; Supervision - M.M.N.E.; Data Collection and/or Processing - M.M.N.E.; Analysis and/ or Interpretation - N.Ü., U.A.; Literature Search - M.M.N.E.; Writing Manuscript - M.M.N.E.; Critical Review - K.K.

Conflict of Interest: No conflict of interest was declared by the authors.

Financial Disclosure: The authors declared that this study received no financial support.

\section{References}

1. Karabağlı H, Karabağlı P. Koroid pleksus tümörleri. Türk Nöroșir Derg 2014; 24: $68-7$.

2. Laarakker AS, Nakhla J, Kobets A, Abbott R. Incidental choroid plexus papilloma in a child: A difficult decision. Surg Neurol Int 2017; 8: 86.

3. Waldron JS, Tihan T: Epidemiology and pathology of intraventricular tumors. Neurosurg Clin N Am 2003; 14: 469-82.

4. Kapoor A, Aggarwal A, Ahuja CK, Salunke P. Primary choroid plexus papilloma of cerebellopontine angle: An unusual entity in infancy. J Pediatr Neurosci 2016; 11: 287-8.

5. Sethi D, Arora R, Garg K, Tanwar P. Choroid plexus papilloma. Asian J Neurosurg 2017; 12: 139-41.

6. Jaiswal AK, Jaiswal S, Sahu RN, Das KB, Jain VK, Behari S. Choroid plexus papilloma in children: Diagnostic and surgical considerations. J Pediatr Neurosci 2009; 4: 10-6.

7. Wolff JE, Sajedi M, Brant R, Coppes MJ, Egeler RM. Choroid plexus tumours. Br J Cancer 2002; 87: 1086-91. 